\title{
Reactive Oxygen Species Mediate Cellular Damage in Alzheimer Disease
}

\author{
George Perry ${ }^{a, *}$, Rudy J. Castellani ${ }^{b}$, \\ Keisuke Hirai ${ }^{a}$ and Mark A. Smith ${ }^{a}$ \\ ${ }^{a}$ Institute of Pathology, Case Western \\ Reserve University, 2085 Adelbert Road, \\ Cleveland, $\mathrm{OH} 44106$, USA \\ ${ }^{b}$ Department of Pathology, Division of \\ Anatomic Pathology, University of Maryland \\ Medical System, 22 South Green Street, \\ Baltimore, MD 21201, USA
}

\begin{abstract}
The two most striking features of Alzheimer disease are (i) the multitude of abnormalities affecting essentially every system and (ii) the strict age dependence. Recent work suggests that both features are linked to increased oxidative stress that damages lipids, proteins and nucleic acids and results in redox-active metal accumulations, mitochondrial damage and formation of advanced glycation endproducts. Interestingly, $\beta$-protein precursor, amyloid- $\beta$, presenilins, and apolipoprotein $\mathrm{E}$ have all been linked to reactive oxygen species production or apoptosis, a process intimately associated with oxidative stress. In therapeutics, the commonality between a number of efficacious agents appears to be oxidative stress reduction. Therefore, we contend that oxidative stress is the element that links the multitude of changes in Alzheimer disease and that a reduction of oxidative stress will have a dramatic effect on reducing the incidence or progression of Alzheimer disease.
\end{abstract}

\section{INTRODUCTION}

A number of reports have established damage from reactive oxygen species (ROS) not only in the lesions of Alzheimer disease but also in

\footnotetext{
* Correspondence author. Tel.: +1 216 368-2488; Fax: +1 216 3688964; E-mail: gxp7@po.cwru.edu.
}

neuronal populations affected in the disease $(86,102-110)$. Now, studies are being focused on the relationship between oxidative stress and other factors that have been established by genetic or epidemiological studies that play an important role in Alzheimer disease. Specifically, we want to determine whether oxidative stress is a central process in neurodegeneration in Alzheimer disease or instead a result of the disease process (Figure 1).

The distinction of whether damage from oxidative stress occurs before neuronal destruction is essential to whether therapeutic reduction of oxidative stress will be efficacious.

Here we present evidence that oxidative damage is one of the earliest cytopathological markers of neuronal dysfunction in Alzheimer disease and, moreover, impinges on all proposed pathogenic risk factors and mechanisms implicated in Alzheimer disease.

\section{Alzheimer Disease Involves a Multitude of Abnormalities}

The pathological presentation of Alzheimer disease, the leading cause of senile dementia, involves regionalized neuronal death and an accumulation of intraneuronal and extracellular

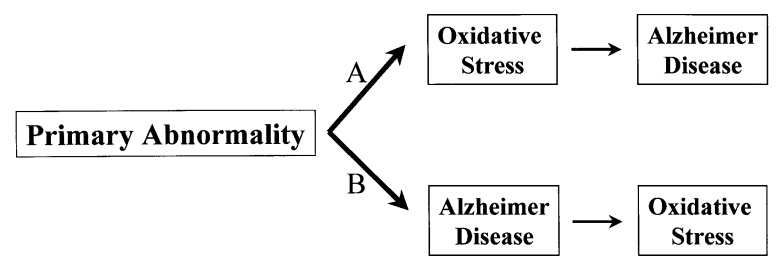

Fig. 1. A central issue is whether oxidative stress is an early event in Alzheimer disease (A) or instead, is a result of degenerative process $(\mathrm{B})$. 
lesions termed neurofibrillary tangles and senile plaques, respectively (reviewed in (111)). Several independent hypotheses have been proposed to link the pathological lesions and neuronal cytopathology with, among others, apolipoprotein E genotype $(17,84)$, hyperphosphorylation of cytoskeletal proteins (119), and amyloid- $\beta$ metabolism (92). However, not one of these theories alone is sufficient to explain the diversity of biochemical and pathological abnormalities found in Alzheimer disease that involves a multitude of cellular and biochemical changes. Furthermore, attempts to mimic the disease by a perturbation of one of these elements using cell or animal models, including transgenic animals, do not result in the same spectrum of pathological alterations. The most striking case is that while amyloid- $\beta$ plaques are deposited in some transgenic rodent models overexpressing $\beta$ protein precursor, there is no neuronal loss $(44,45)$ - a seminal feature of Alzheimer disease.

\section{Oxidative Theory of Aging}

What many theories have failed to incorporate is that Alzheimer disease is a disease of aging (49) (Figure 2). Importantly, this holds true even in individuals with a genetic predisposition, i.e., those individuals with an autosomal dominant inheritance of Alzheimer disease or in individuals with Down's syndrome who develop the pathology of Alzheimer disease. Therefore, age is a clear contributor in $100 \%$ of Alzheimer disease cases, whatever the genetic background. The free radical theory of aging (36) hypothesizes that the aging process is associated with (i) an increase in the adventitious production of oxygen-derived radicals, i.e., reactive oxygen species (ROS), together with (ii) a concurrent decrease in the ability to defend against such ROS, that together lead to the accumulation of oxidatively-modified macromolecules. We suggest that the decrease in ROS buffering capacity may also lead to a compromised ability to deal with abnormal sources of ROS such as those associated with genetic predisposition and/or disease status.

\section{Sources of Reactive Oxygen Species}

ROS production occurs as a ubiquitous byproduct of both oxidative phosphorylation and the myriad of oxidases necessary to support aerobic metabolism. In Alzheimer disease, in addition to this background level of ROS, there are a number of additional contributory sources that are thought to play an important role in the disease process: 1. Iron, in a redox-active state, is increased in neurofibrillary tangles as well as in amyloid- $\beta$ deposits $(28,110)$. Iron catalyzes the formation of $\bullet \mathrm{OH}$ from $\mathrm{H}_{2} \mathrm{O}_{2}$ as well as the formation of advanced glycation end products. Furthermore, aluminum, which also accumulates in neurofibrillary tangle-containing neurons (28), stimulates iron-induced lipid peroxidation (69). 2. Activated microglia, such as those that surround most senile plaques (20), are a source of $\mathrm{NO}$ and $\mathrm{O}_{2}^{-}$(16) which can react to form peroxynitrite, leaving nitrotyrosine as an identifiable marker $(29,109)$. 3. Amyloid- $\beta$ itself has been directly implicated in ROS formation through peptidyl radicals $(10,39,87)$. 4 . Advanced glycation end products in the presence of transition metals (see above) can undergo redox cycling with consequent ROS production $(3,126,127)$. Additionally, advanced glycation end products and amyloid- $\beta$ activate specific receptors, such as the receptor for advanced

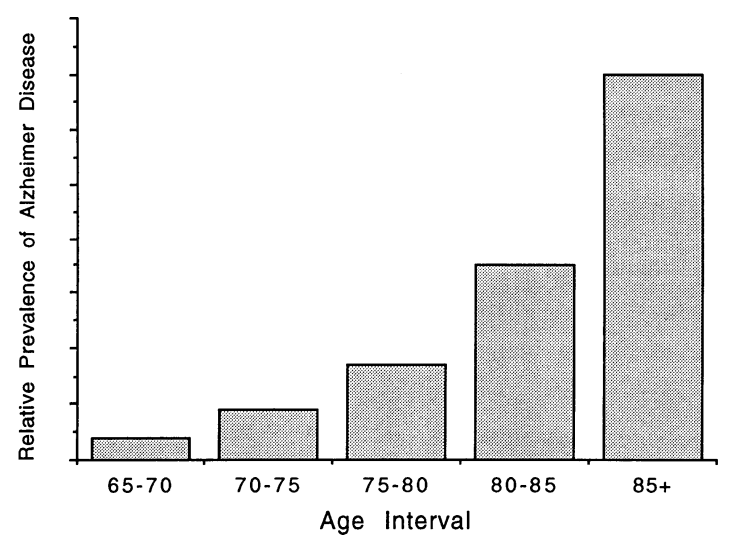

Fig. 2. Alzheimer disease, genetic as well as sporadic, always has a strict age related incidence. 
glycation end products (RAGE) and the class A scavenger-receptor, to increase ROS production $(23,128)$. 5. Abnormalities in the mitochondrial genome $(18,22)$ or deficiencies in key metabolic enzymes $(8,96,71,94,112)$ suggest that metabolic abnormalities affecting mitochondria may be the major and possible initiating source of ROS in AD.

\section{Oxidative Damage and Response}

An exact determination of the contribution of each source of oxidative stress is complicated, if for no other reason than that most sources have positive feedback. Nonetheless, the overall result is damage including advanced glycation end products $(53,102,123,126)$, nitration $(29,109)$, lipid peroxidation adduction products $(63,86)$ as well as carbonyl-modified neurofilament protein and free carbonyls $(99,105,107)$ with the involvement extending beyond the lesions to neurons not displaying obvious degenerative change.

Oxidative crosslinking makes proteins not only insoluble (reviewed in 104,108) but also resistant to proteolytic removal (21) by competitively inhibiting the proteosome (24). Therefore, oxidative crosslinking may be significant in the accumulation of ubiquitin conjugates in neurofibrillary tangles $(65,72)$ in the face of numerous proteolytic activities, which are highly active against abnormal proteins (101). Indeed, it may not be coincidental that fibrillary inclusions found in neurodegenerative diseases other than Alzheimer disease are also extensively ubiquinated, e.g., Lewy/Pick bodies and Rosenthal fibers $(25,55)$ and are also oxidatively modified (12-14).

The cytopathological significance of oxidative damage is seen by the upregulation of the antioxidant enzyme heme oxygenase-1 in neurons with NFT $(78,89,103)$. Furthermore, in quantitative immunocytochemical studies of cases of Alzheimer disease, there is a complete overlap between heme oxygenase-1 and Alz50, an early marker of $\tau$ abnormalities, indicating that cytoskeletal abnormalities are associated with increased oxidative stress or vice versa (Smith and Perry, unpublished observation).

\section{Phosphorylation}

The mechanisms by which normal soluble cytoskeletal elements, such as $\tau$ and neurofilaments, are transformed into insoluble paired helical filaments is an important issue $(91,108)$. Insolubility has been linked to the most well known posttranslational change of $\tau$ abnormal phosphorylation $(27,31)$ and a number of specific kinases and phosphates have been implicated (reviewed in (119)). However, while increased phosphorylation decreases microtubule stability, a salient feature of the pathology of Alzheimer disease $(1,2,43,73,75,76)$, NFT insolubility is not mediated by phosphorylation (108). Indeed, in vitro phosphorylation of normal $\tau$ or complete dephosphorylation of NFT has no effect on their solubility $(27,31,33,108)$. Instead, recent studies suggest $\tau$ phosphorylation as found in Alzheimer disease may be part of a novel process similar to that seen during mitosis $(74,79)$ suggesting that neurons affected in the disease might be abortively entering the cell cycle $(60,61,122)$.

Phosphorylation is intimately tied to oxidative stress by the mitogen activated phosphorylation (MAP) pathway (34) as well as through activation of transcription factor NFKB (90). While there is controversy concerning the kinases involved in the phosphorylation of $\tau$ in Alzheimer disease, the MAP kinase pathway is implicated $(41,52,120)$. In studies with antibodies specific to activated MAP kinase, we found activity in all pyramidal hippocampal neurons in cases of Alzheimer disease but none in young controls. In aged controls, active MAP kinase is found not only in the few Alz50- or phosphorylated $\tau$ (AT8)-positive neurons but also in many apparently normal neurons. Preliminary studies show many of the same neurons showing active MAP kinase show increased nitration. Therefore, abnormal phosphorylation of proteins in Alzheimer disease may be a consequence of oxidative stress. Moreover, it is perhaps not 


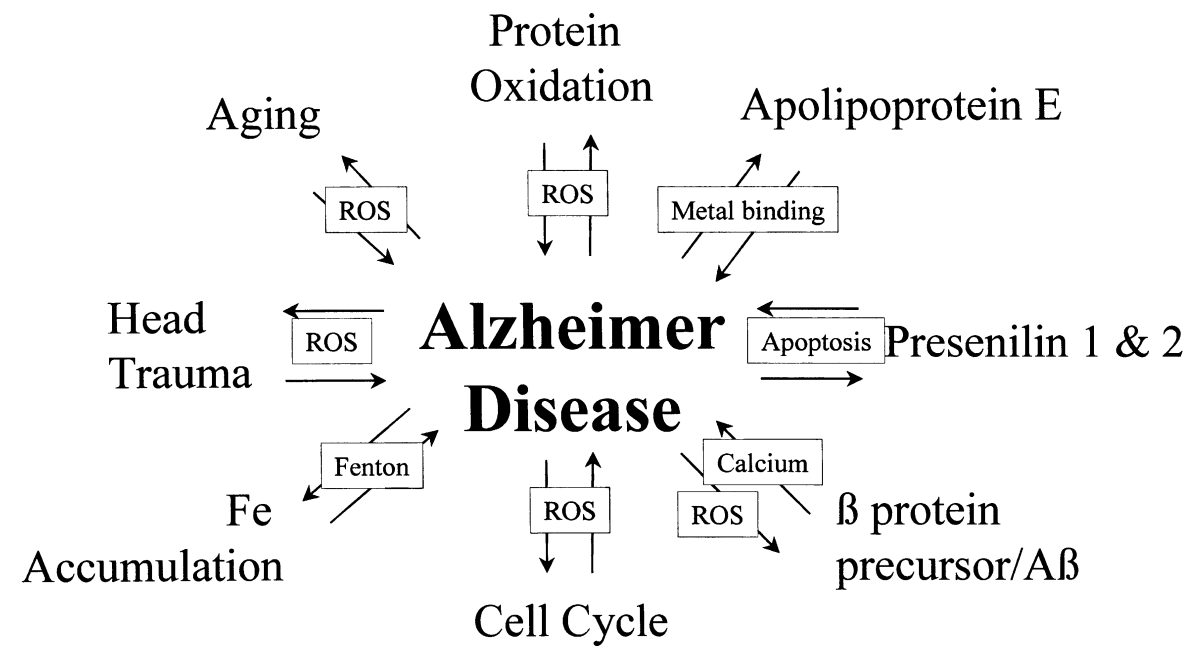

Fig. 3. All of the known factors implicated in Alzheimer disease are directly linked to oxidative stress.

surprising that, while all pyramidal neurons of the hippocampus show increased free carbonyls (107), lipid peroxide adduction (86) and nitrotyrosine (109), only a subset of neurons displaying overt degeneration also show increased phosphorylation (32,113). Heme oxygenase-1, an inducible antioxidant enzyme, also shows the same pattern of involvement since it accumulates concurrent with phosphorylated $\tau$ (Smith and Perry, unpublished data).

\section{Amyloid- $\beta$}

The influences of amyloid- $\beta$ and other genetic factors on Alzheimer disease may be through their effect on oxidative stress (Figure 3). A number of mechanisms have been invoked for the neurotoxicity of amyloid- $\beta$ (129), reviewed in $(46,87)$, including membrane depolarization (11), increased sensitivity to excitotoxins (51), and alterations in calcium homeostasis (56). However, the leading hypothesis is that neuronal damage by amyloid- $\beta$ is mediated by free radicals and, as such, can be attenuated using antioxidants such as vitamin E $(4,5)$ or catalase $(54,130)$. Indeed, amyloid- $\beta$ is reported to spontaneously generate peptidyl radicals $(10,30,37,77)$. Further, mutations in $\beta$-precursor protein are associated with increased DNA fragmentation, possibly involving oxidative mechanisms (see below). Critically addressing whether amyloid- $\beta$ initiates oxidative damage in Alzheimer disease requires careful study of the relationship of amyloid- $\beta$ deposition and increased oxidative damage. In this regard, it will be extremely interesting to determine the oxidative status of the recently reported transgenic rodent models of amyloid- $\beta$ deposition $(26,40)$. Preliminary findings from our laboratory, in collaboration with Karen Hsiao and Miguel Pappolla, that indicate the full spectrum of oxidative changes of Alzheimer disease are found in neurons of transgenic mice with amyloid- $\beta$ deposits (111).

\section{Genetic Factors}

Presenilins 1 and $2(92,93)$ are genetic factors where the biological mechanism, although not established, may also involve oxidative damage. Increased presenilin 2 expression increases DNA fragmentation and apoptotic changes (124), both important consequences of oxidative damage. Apolipoprotein E, in brains and cerebrospinal fluid, is found adducted with the highly reactive lipid peroxidation product, hydroxynonenal (64). Furthermore, apolipoprotein $\mathrm{E}$ is a strong chelator of copper and iron, important redoxactive transition metals (62). Finally, interaction of apolipoprotein $E$ with amyloid- $\beta$ only occurs in the presence of oxygen (116). 


\section{Apoptosis}

In programmed cell death, i.e., apoptosis, cells are digested within their own membrane by proteases and nucleases as well as by increased ROS. However, without the full range of morphological changes, it is unclear whether DNA fragmentation is apoptotic or is, instead, mediated solely by oxidative stress (7). The relative contribution of oxidative stress- and apoptosis-related DNA fragmentation in $\mathrm{AD}$ is unresolved. Yet bearing on this issue, the relative infrequency of apoptosis defined by morphology $(19,117)$ and the broad findings of fragmentation in all cells in cases of Alzheimer disease argues for widespread oxidative DNA damage rather than widespread apoptosis. Certainly, this interpretation is consistent with the oxidative nuclear damage in all cells of the brain in areas affected in Alzheimer disease $(107,110)$.

\section{Therapeutics}

An important question in discerning whether reducing oxidative stress may have therapeutic value is whether it is a primary or secondary event in disease pathogenesis $(57,106)$ (Figure 4). Recent evidence, reviewed above, supports oxidative damage as the earliest cytopathological and biochemical change of Alzheimer disease $(53,86,102,104,107,109,123,126)$.

Agents that inhibit free radical formation $(6,35,42,47,68,81,83,88,95,121,125)$, reduce both the incidence and the progression of Alzheimer

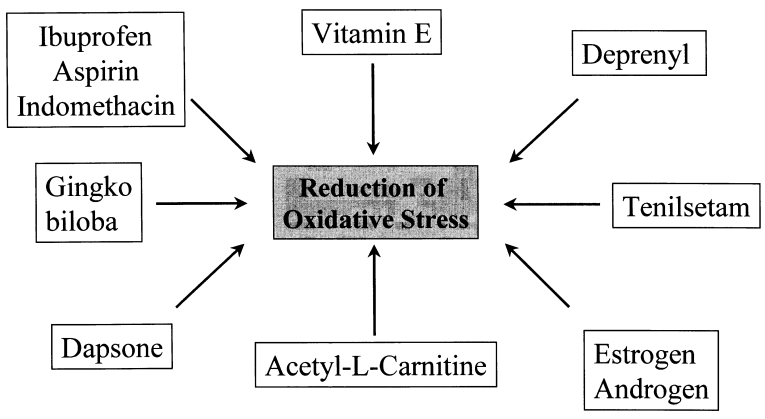

Fig. 4. All known therapeutic agents for Alzheimer's disease, save palliative cholinergics, share antioxidant activity. disease (Figure 4) $(9,15,38,48,50,58,66,67,70,80$, $82,85,95,97,98,114,115,118)$. This relationship, together with the efficacy of metal chelation treatment (59), strongly suggest that oxidative stress precedes cell and tissue damage and therefore agents that prevent oxidative damage show promise in the treatment of Alzheimer disease.

\section{CONCLUSION}

In summary, oxidative stress may underline all of the commonly accepted notions in Alzheimer disease pathogenesis, including hyperphosphorylation, apolipoprotein E genotype, and mutations of the $\beta$-protein precursor. Further studies, to examine the types and extent of oxidative damage, will undoubtedly identify which antioxidant agents will prove most efficacious in the treatment of Alzheimer disease.

\section{ACKNOWLEDGMENTS}

This work was supported through grants from the National Institutes of Health (AG09287), the American Health Assistance Foundation (AHAF) and the Alzheimer's Association.

\section{REFERENCES}

1. Alonso AC, Zaidi T, Grundke-Iqbal I, Iqbal K, Role of abnormally phosphorylated tau in the breakdown of microtubules in Alzheimer disease, Proc Natl Acad Sci USA 91 (1994) 5562-5566.

2. Alonso AC, Grundke-Iqbal I, Iqbal K, Alzheimer's disease hyperphosphorylated tau sequesters normal tau into tangles of filaments and disassembles microtubules, Nature Med 2 (1996) 783-787.

3. Baynes JW, Role of oxidative stress in development of complications in diabetes, Diabetes 40 (1991) 405-412.

4. Behl C, Davis J, Cole GM, Schubert D, Vitamin $\mathrm{E}$ protects nerve cells from amyloid- $\beta$ protein toxicity, Biochem Biophys Res Commun 186 (1992) 944-950. 
5. Behl C, Davis JB, Lesley R, Schubert D, Hydrogen peroxide mediates amyloid $\beta$ protein toxicity, Cell 77 (1994) 817-827.

6. Behl C, Skutella T, Lezoualc'h F, Post A, Widmann M, Newton CJ, Holsboer F, Neuroprotection against oxidative stress by estrogens: structure-activity relationship, Mol Pharmacol 51 (1997) 535-541.

7. Berlin V, Haseltine WA, Reduction of adriamycin to a semiquinone-free radical by NADPH cytochrome P-450 reductase produces DNA cleavage in a reaction mediated by molecular oxygen, J Biol Chem 256 (1981) 4747-4756.

8. Blass JP, Baker AC, Ko L, Black RS, Induction of Alzheimer antigens by an uncoupler of oxidative phosphorylation, Arch Neurol 47 (1990) 864-869.

9. Breitner JCS, Gau BA, Welsh KA, Plassman BL, McDonald WM, Helms MJ, Anthony J, Inverse association of anti-inflammatory treatments and Alzheimer's disease: initial results of a co-twin control study, Neurology 44 (1994) 227-232.

10. Butterfield DA, Hensley K, Harris M, Mattson M, Carney J, $\beta$-amyloid peptide free radical fragments initiate synaptosomal lipoperoxidation in a sequence-specific fashion: implications to Alzheimer's disease, Biochem Biophys Res Commun 200 (1994) 710-715.

11. Carette B, Poulain P, Delacourte A, Electrophysiological effects of 25-35 amyloid- $\beta$ protein on guinea pig lateral septal neurons, Neurosci Lett 151 (1993) 111-114.

12. Castellani R, Smith MA, Richey PL, Kalaria R, Gambetti P, Perry G, Evidence for oxidative stress in Pick disease and corticobasal degeneration, Brain Res 696 (1995) 268-271.

13. Castellani R, Smith MA, Richey PL, Perry G, Glycoxidation and oxidative stress in Parkinson disease and diffuse Lewy body disease, Brain Res 737 (1996) 195-200.

14. Castellani RJ, Perry G, Harris PLR, Monnier VM, Cohen ML, Smith MA, Advanced glycation modification of Rosenthal fibers in Alexander disease, Neurosci Lett 231 (1997) 79-82.

15. Colaco CA, Ledesma MD, Harrington CR, Avila $\mathrm{J}$, The role of the Mailard reaction in other pathologies: Alzheimer's disease, Nephrology, Dialysis, Transplantation 11 (Suppl 5) (1996) 7 12.

16. Colton CA, Gilbert DL, Production of superoxide anions by a CNS macrophage, the microglia,
FEBS Lett 223 (1987) 284-288.

17. Corder EH, Saunders AM, Strittmatter WJ, Schmechel DE, Gaskell PC, Small GW, Roses AD, Haines JL, Pericak-Vance MA, Gene dose of apolipoprotein E type 4 allele and the risk of Alzheimer's disease in late onset families, Science 261 (1993) 921-923.

18. Corral-Debrinski M, Horton T, Lott MT, Shoffner JM, McKee AC, Beal MF, Graham BH, Wallace DC, Marked changes in mitochondrial DNA deletion levels in Alzheimer brains, Genomics 23 (1994) 471-476.

19. Cotman $\mathrm{CW}, \mathrm{Su} \mathrm{JH}$, Mechanisms of neuronal death in Alzheimer's disease, Brain Pathol 6 (1996) 493-506.

20. Cras P, Kawai M, Siedlak S, Mulvihill P, Gambetti P, Lowery D, Gonzalez-DeWhitt P, Greenberg B, Perry G, Neuronal and microglial involvement in $\beta$-amyloid protein deposition in Alzheimer's disease, Am J Pathol 137 (1990) 241-246.

21. Cras P, Smith MA, Richey PL, Siedlak SL, Mulvihill P, Perry G, Extracellular neurofibrillary tangles reflect neuronal loss and provide further evidence of extensive protein cross-linking in Alzheimer disease, Acta Neuropathol 89 (1995) 291-295.

22. Davis RE, Miller S, Herrnstadt C, Ghosh SS, Fahy E, Shinobu LA, Galasko D, Thal LJ, Beal MF, Howell N, Parker WD Jr, Mutations in mitochondrial cytochrome $\mathrm{c}$ oxidase genes segregate with late-onset Alzheimer disease, Proc Natl Acad Sci USA 94 (1997) 4526-4531.

23. El Khoury J, Hickman SE, Thomas CA, Cao L, Silverstein SC, Loike JD, Scavenger receptormediated adhesion of microglia to $\beta$-amyloid fibrils, Nature 382 (1996) 716-719.

24. Friguet B, Stadtman ER, Szweda LI, Modification of glucose-6-phosphate dehydrogenase by 4hydroxy-2-nonenal. Formation of cross-linked protein that inhibits the multicatalytic protease, $\mathrm{J}$ Biol Chem 269 (1994) 21639-21643.

25. Galloway PG, Grundke-Iqbal I, Iqbal K, Perry G, Lewy bodies contain epitopes both shared and distinct from Alzheimer neurofibrillary tangles, $\mathrm{J}$ Neuropathol Exp Neurol 47 (1988) 654-663.

26. Games D, Adams D, Alessandrini R, Barbour R, Berthelette P, Blackwell C, Carr T, Clemens J, Donaldson T, Gillespie F, Guido T, Hagopian S, Johnson-Wood K, Khan K, Lee M, Leibowitz P, Lieberburg I, Little S, Masliah E, McConlogue L, 
Montoya-Zavala M, Mucke L, Paganini L, Penniman E, Power M, Schenk D, Seubert P, Snyer B, Soriano F, Tan H, Vitale J, Wadsworth S, Wolozin B, Zhao J, Alzheimer-type neuropathology in transgenic mice overexpressing V717F $\beta$-amyloid precursor protein, Nature 373 (1995) 523-527.

27. Goedert M, Sisodia SS, Price DL, Neurofibrillary tangles and beta-amyloid deposits in Alzheimer's disease, Curr Opin Neurobiol 1 (1991) 441-447.

28. Good PF, Perl DP, Bierer LM, Schmeidler J, Selective accumulation of aluminum and iron in the neurofibrillary tangles of Alzheimer's disease: a laser microprobe (LAMMA) study, Ann Neurol 31 (1992) 286-292.

29. Good PF, Werner P, Hsu A, Olanow CW, Perl DP, Evidence of neuronal oxidative damage in Alzheimer's disease, Am J Pathol 149 (1996) 2128.

30. Goodman Y, Steiner MR, Steiner SM, Mattson MP, Nordihydroguaiaretic acid protects hippocampal neurons against amyloid betapeptide toxicity, and attenuates free radical and calcium accumulation, Brain Res 654 (1994) 171-176.

31. Greenberg SG, Davies P, Schein JD, Binder LI, Hydrofluoric acid-treated tau PHF proteins display the same biochemical properties as normal tau, J Biol Chem 267 (1992) 564-569.

32. Grundke-Iqbal I, Iqbal K, Tung YC, Quinlan M, Wisniewski HM, Binder LI, Abnormal phosphorylation of the microtubule-associated protein $\tau$ (tau) in Alzheimer cytoskeletal pathology, Proc Natl Acad Sci USA 83 (1986) 4913-4917.

33. Gustke N, Steiner B, Mandelkow EM, Biernat J, Meyer HE, Goedert M, Mandelkow E, The Alzheimer-like phosphorylation of tau protein reduces microtubule binding and involves Ser-Pro and Thr-Pro motifs, FEBS Lett 307 (1992) 199_ 205.

34. Guyton KZ, Liu Y, Gorospe M, Xu Q, Holbrook NJ, Activation of mitogen-activated protein kinase by $\mathrm{H}_{2} \mathrm{O}_{2}$. Role in cell survival following oxidant injury, J Biol Chem 271 (1996) 41384142.

35. Hamburger SA, McCay PB, Spin trapping of ibuprofen radicals: evidence that ibuprofen is a hydroxyl radical scavenger, Free Radic Res Commun 9 (1990) 337-342.
36. Harman D, Ageing: a theory based on free radical and radiation chemistry, J Gerontol 11 (1956) 298-300.

37. Harris ME, Carney JM, Cole PS, Hensley K, Howard BJ, Martin L, Bummer P, Wang Y, Pedigo NW Jr, Butterfield DA, $\beta$-amyloid peptide-derived, oxygen-dependent free radicals inhibit glutamate uptake in cultured astrocytes: implications for Alzheimer's disease, Neuroreport 6 (1995) 1875-1879.

38. Henderson VW, The epidemiology of estrogen replacement therapy and Alzheimer's disease, Neurology 48(Suppl 7) (1997) S27-S35.

39. Hensley K, Carney JM, Mattson MP, Aksenova M, Harris M, Wu JF, Floyd RA, Butterfield DA, A model for $\beta$-amyloid aggregation and neurotoxicity based on free radical generation by the peptide: relevance to Alzheimer disease, Proc Natl Acad Sci USA 91 (1994) 3270-3274.

40. Hsiao K, Chapman P, Nilsen S, Eckman C, Harigaya Y, Younkin S, Yang F, Cole G, Correlative memory deficits, $A \beta$ elevation, and amyloid plaques in transgenic mice, Science 274 (1996) 99-102.

41. Hyman BT, Elvhage TE, Reiter J, Extracellular signal regulated kinases. Localization of protein and mRNA in the human hippocampal formation in Alzheimer's disease, Am J Pathol 144 (1994) 565-572.

42. Igawa K, Maruyama R, Katayama I, Nishioka K, Anti-oxidative therapy with oral dapsone improved $\mathrm{HCV}$ antibody positive annular elastolytic giant cell granuloma, J Dermatology 24 (1997) 328-331.

43. Iqbal K, Zaidi T, Bancher C, Grundke-Iqbal I, Alzheimer paired helical filaments. Restoration of the biological activity by dephosphorylation, FEBS Lett 349 (1994) 104-108.

44. Irizarry MC, McNamara M, Fedorchak K, Hsiao $\mathrm{K}$, Hyman BT, APPSw transgenic mice develop age-related A beta deposits and neuropil abnormalities, but no neuronal loss in CA1, J Neuropathol Exp Neurol 56 (1997) 965-973.

45. Irizarry MC, Soriano F, McNamara M, Page KJ, Schenk D, Games D, Hyman BT, A $\beta$ deposition is associated with neuropil changes, but not with overt neuronal loss in the human amyloid precursor protein V717F (PDAPP) transgenic mouse, J Neurosci 17 (1997) 7053-7059. 
46. Iversen LL, Mortishire-Smith RJ, Pollack SJ, Shearman MS, The toxicity in vitro of $\beta$-amyloid protein, Biochem J 331 (1995) 1-16.

47. Jones LH, Abdalla DS, Freitas JC, Effects of indole-3-acetic acid on croton oil- and arachidonic acid-induced mouse ear edema, Inflammation Res 44 (1995) 372-375.

48. Kanowski S, Herrmann WM, Stephan K, Wierich W, Horr R, Proof of efficacy of the ginkgo biloba special extract EGb 761 in outpatients suffering from mild to moderate primary degenerative dementia of the Alzheimer type or multi-infarct dementia, Pharmacopsychiatry 29 (1996) 47-56.

49. Katzman R, Alzheimer's disease, N Engl J Med 314 (1986) 964-973.

50. Kawas C, Resnick S, Morrison A, Brookmeyer R, Corrada M, Zonderman A, Bacal C, Lingle DD, Metter E, A prospective study of estrogen replacement therapy and the risk of developing Alzheimer's disease: the Baltimore Longitudinal Study of Aging, Neurology 48 (1997) 1517-1521.

51. Koh JY, Yang LL, Cotman CW, $\beta$-amyloid protein increases the vulnerability of cultured cortical neurons to excitotoxic damage, Brain Res 533 (1990) 315-320.

52. Ledesma MD, Correas I, Avila J, Diaz-Nido J, Implication of brain cdc2 and MAP2 kinases in the phosphorylation of tau protein in Alzheimer's disease, FEBS Lett 308 (1992) 218-224.

53. Ledesma MD, Bonay $\mathrm{P}$, Colaco C, Avila J, Analysis of microtubule-associated protein tau glycation in paired helical filaments, J Biol Chem 269 (1994) 21614-21619.

54. Lockhart BP, Benicourt C, Junien JL, Privat A, Inhibitors of free radical formation fail to attenuate direct $\beta$-amyloid -25-35 $_{2}$ peptide-mediated neurotoxicity in rat hippocampal cultures, J Neurosci Res 39 (1994) 494-505.

55. Manetto V, Abdul-Karim FW, Perry G, Tabaton M, Autilio-Gambetti L, Gambetti P, Selective presence of ubiquitin in intracellular inclusions, Am J Pathol 134 (1989) 505-513.

56. Mattson MP, Cheng B, Davis D, Bryant K, Lieberburg I, Rydel RE, $\beta$-amyloid peptides destabilize calcium homeostasis and render human cortical neurons vulnerable to excitotoxicity, J Neurosci 12 (1992) 376-389.

57. Mattson MP, Carney JW, Butterfield DA, A tombstone in Alzheimer's?, Nature 373 (1995) 481 .
58. McGeer PL, Rogers J, Anti-inflammatory agents as a therapeutic approach to Alzheimer's disease, Neurology 42 (1992) 447-449.

59. McLachlan DR, Kruck TP, Lukiw WJ, Krishnan $\mathrm{SS}$, Would decreased aluminum ingestion reduce the incidence of Alzheimer's disease?, Can Med Assoc J 145 (1991) 793-804.

60. McShea A, Harris PLR, Webster KR, Wahl A, Smith MA, Abnormal expression of the cell cycle regulators P16 and CDK4 in Alzheimer's disease, Am J Pathol 150 (1997) 1933-1939.

61. McShea A, Wahl AF, Smith MA, Re-entry into the cell cycle: a mechanism for neurodegeneration in Alzheimer disease, Med Hypotheses (1998) in press.

62. Miyata M, Smith JD, Apolipoprotein E allellespecific antioxidant activity and effects on cytotoxicity by oxidative insults and $\beta$-amyloid peptides, Nature Genetics 14 (1996) 55-61.

63. Montine TJ, Amarnath V, Martin ME, Strittmatter WJ, Graham DG, E-4-hydroxy-2-nonenal is cytotoxic and cross-links cytoskeletal proteins in P19 neuroglial cultures, Am J Pathol 148 (1996) 89-93.

64. Montine TJ, Huang DY, Valentine WM, Amarnath V, Saunders A, Weisgraber KH, Graham DG, Strittmatter WJ, Crosslinking of apolipoprotein $\mathrm{E}$ by products of lipid peroxidation, J Neuropathol Exp Neurol 55 (1996) 202-210.

65. Mori H, Kondo J, Ihara Y, Ubiquitin is a component of paired helical filaments in Alzheimer's disease, Science 235 (1987) 16411644.

66. Münch G, Taneli Y, Schraven E, Schindler U, Schinzel R, Palm D, Riederer P, The cognitionenhancing drug tenilsetam is an inhibitor of protein crosslinking by advanced glycosylation, J Neural Trans-Parkinsons Dis Dem Sect 8 (1994) 193-208.

67. Münch G, Mayer S, Michaelis J, Hipkiss AR, Riederer P, Muller R, Neumann A, Schinzel R, Cunningham AM, Influence of advanced glycation end-products and AGE-inhibitors on nucleation-dependent polymerization of betaamyloid peptide, Biochim Biophys Acta 1360 (1997) 17-29.

68. Neuzil J, Witting PK, Stocker R, Alphatocopheryl hydroquinone is an efficient multifunctional inhibitor of radical-initiated 
oxidation of low density lipoprotein lipids, Proc Natl Acad Sci USA 94 (1997) 7885-7890.

69. Oteiza PI, A mechanism for the stimulatory effect of aluminum on iron-induced lipid peroxidation, Arch Biochem Biophys 308 (1994) 374-379.

70. Papasozomenos SC, The heat shock-induced hyperphosphorylation of tau is estrogenindependent and prevented by androgens: implications for Alzheimer disease, Proc Natl Acad Sci USA 94 (1997) 6612-6617.

71. Parker WD Jr, Filley CM, Parks JK, Cytochrome oxidase deficiency in Alzheimer's disease, Neurology 40 (1990) 1302-1303.

72. Perry G, Friedman R, Shaw G, Chau V, Ubiquitin is detected in neurofibrillary tangles and senile plaque neurites of Alzheimer disease brains, Proc Natl Acad Sci USA 81 (1987) 3033-3036.

73. Perry G, Kawai M, Tabaton M, Onorato M, Mulvihill P, Richey P, Morandi A, Connolly JA, Gambetti P, Neuropil threads of Alzheimer's disease show a marked alteration of the normal cytoskeleton, J Neurosci 11 (1991) 1748-1755.

74. Pope WB, Lambert MP, Leypold B, Seupaul R, Sletten L, Krafft G, Klein WL, Microtubuleassociated protein tau is hyperphosphorylated during mitosis in the human neuroblastoma cell line SH-SY5Y, Exp Neurol 126 (1994) 185-194.

75. Praprotnik D, Smith MA, Richey PL, Vinters HV, Perry G, Plasma membrane fragility in dystrophic neurites in senile plaques of Alzheimer's disease: an index of oxidative stress, Acta Neuropathol 91 (1996) 1-5.

76. Praprotnik D, Smith MA, Richey PL, Vinters HV, Perry G, Filament heterogeneity within the dystrophic neurites of senile plaques suggests blockage of fast axonal transport in Alzheimer's disease, Acta Neuropathol 91 (1996) 226-235.

77. Prehn JH, Bindokas VP, Jordan J, Galindo MF, Ghadge GD, Roos RP, Boise LH, Thompson CB, Krajewski S, Reed JC, Miller RJ, Protective effect of transforming growth factor- $\beta 1$ on $\beta$-amyloid neurotoxicity in rat hippocampal neurons, Mol Pharmacol 49 (1996) 319-328.

78. Premkumar DRD, Smith MA, Richey PL, Petersen RB, Castellani R, Kutty RK, Wiggert B, Perry G, Kalaria RN, Induction of heme oxygenase-1 mRNA and protein in neocortex and cerebral vessels in Alzheimer's disease, J Neurochem 65 (1995) 1399-1402.

79. Preuss U, Doring F, Illenberger S, Mandelkow EM, Cell cycle-dependent phosphorylation and microtubule binding of tau protein stably transfected into Chinese hamster ovary cells, Mol Biol Cell 6 (1995) 1397-1410.

80. Rich JB, Rasmusson DX, Folstein MF, Carson KA, Kawas C, Brandt J, Nonsteroidal antiinflammatory drugs in Alzheimer's disease, Neurology 45 (1995) 51-55.

81. Ripple MO, Henry WF, Rago RP, Wilding G, Prooxidant-antioxidant shift induced by androgen treatment of human prostate carcinoma cells, J Natl Cancer Inst 89 (1997) 40-48.

82. Rogers J, Kirby LC, Hempelman SR, Berry DL, McGeer PL, Kaszniak AW, Zalinski J, Cofield M, Mansukhani L, Willson P, Kogan F, Clinical trial of indomethacin in Alzheimer's disease, Neurology 43 (1993) 1609-1611.

83. Rong Y, Geng Z, Lau BH, Ginkgo biloba attenuates oxidative stress in macrophages and endothelial cells, Free Radic Biol Med 20 (1996) 121-127.

84. Roses $\mathrm{AD}$, On the metabolism of apolipoprotein E and the Alzheimer diseases, Exp Neurol 132 (1995) 149-156.

85. Sano M, Ernesto C, Thomas RG, Klauber MR, Schafer K, Grundman M, Woodbury P, Growdon J, Cotman CW, Pfeiffer E, Schneider LS, Thal LJ, A controlled trial of selegiline, alpha-tocopherol, or both as treatment for Alzheimer's disease. The Alzheimer's Disease Cooperative Study, New Eng J Med 336 (1997) 1216-1222.

86. Sayre LM, Zelasko DA, Harris PLR, Perry G, Salomon RG, Smith MA, 4-Hydroxynonenalderived advanced lipid peroxidation end products are increased in Alzheimer's disease, J Neurochem 68 (1997) 2092-2097.

87. Sayre LM, Zagorski MG, Surewicz WK, Krafft GA, Perry G, Mechanisms of neurotoxicity associated with amyloid $\beta$ deposition and the role of free radicals in the pathogenesis of Alzheimer's disease. A critical appraisal, Chem Res Toxicol 10 (1997) 518-526.

88. Schinetti ML, Rossini D, Greco R, Bertelli A, Protective action of acetylcarnitine on NADPHinduced lipid peroxidation of cardiac microsomes, Drugs Under Exp Clin Res 13 (1987) 509-515.

89. Schipper HM, Cisse S, Stopa EG, Expression of heme oxygenase- 1 in the senescent and Alzheimer-diseased brain, Ann Neurol 37 (1995) 758-768.

90. Schreck R, Rieber P, Baeuerle PA, Reactive oxygen intermediates as apparently widely used 
messengers in the activation of the NF- $\kappa B$ transcription factor and $\mathrm{HIV}-1, \mathrm{EMBO} \mathrm{J} 10$ (1991) 2247-2258.

91. Selkoe DJ, Ihara Y, Salazar FJ, Alzheimer's disease: insolubility of partially purified paired helical filaments in sodium dodecyl sulfate and urea, Science 215 (1982) 1243-1245.

92. Selkoe DJ, Alzheimer's disease: genotypes, phenotypes, and treatments, Science 275 (1997) 630-631.

93. Sherrington R, Rogaev EI, Liang Y, Rogaeva EA, Levesque $\mathrm{G}$, Ikeda $\mathrm{M}$, Chi $\mathrm{H}$, Lin $\mathrm{C}$, Li G, Holman K, Tsuda T, Mar L, Foncin J-F, Bruni AC, Montesi MP, Sorbi S, Rainero I, Pinessi L, Polinsky RJ, Wasco W, Da Silva HAR, Haines JL, Pericak-Vance MA, Tanzi RE, Roses AD, Fraser PE, Rommens JM, St. George-Hyslop PH, Cloning of a gene bearing missense mutations in early-onset familial Alzheimer's disease, Nature 375 (1995) 754-760.

94. Sheu KF, Kim YT, Blass JP, Weksler ME, An immunochemical study of the pyruvate dehydrogenase deficit in Alzheimer's disease brain, Ann Neurol 17 (1985) 444-449.

95. Shoda H, Miyata S, Liu BF, Yamada H, Ohara T, Suzuki K, Oimomi M, Kasuga M, Inhibitory effects of tenilsetam on the Maillard reaction, Endocrinology 138 (1997) 1886-1892.

96. Sims NR, Finegan JM, Blass JP, Bowen DM, Neary D, Mitochondrial function in brain tissue in primary degenerative dementia, Brain Res 436 (1987) 30-38.

97. Skolnick AA, Old Chinese herbal medicine used for fever yields possible new Alzheimer disease therapy, JAMA 277 (1997) 776.

98. Smalheiser NR, Swanson DR, Indomethacin and Alzheimer's disease, Neurology 46 (1996) 583.

99. Smith CD, Carney JM, Starke-Reed PE, Oliver CN, Stadtman ER, Floyd RA, Marksberry WR, Excess brain protein oxidation and enzyme dysfunction in normal aging and in Alzheimer disease, Proc Natl Acad Sci USA 88 (1991) 10540-10543.

100.Smith MA, Alzheimer Disease, in: International Review of Neurobiology, RJ Bradley and RA Harris, eds, Academic Press, San Diego, 1998, in press.

101.Smith MA, Perry G, Alzheimer disease: an imbalance of proteolytic regulation?, Med Hypotheses 42 (1994) 277-279.
102. Smith MA, Taneda S, Richey PL, Miyata S, Yan S-D, Stern D, Sayre LM, Monnier VM, Perry G, Advanced Maillard reaction products are associated with Alzheimer disease pathology, Proc Natl Acad Sci USA 91 (1994) 5710-5714.

103. Smith MA, Kutty RK, Richey PL, Yan S-D, Stern D, Chader GJ, Wiggert B, Petersen RB, Perry G, Heme oxygenase-1 is associated with the neurofibrillary pathology of Alzheimer's disease, Am J Pathol 145 (1994) 42-47.

104.Smith MA, Sayre LM, Monnier VM, Perry G, Radical AGEing in Alzheimer's disease, Trends Neurosci 18 (1995) 172-176.

105.Smith MA, Rudnicka-Nawrot M, Richey PL, Praprotnik D, Mulvihill P, Miller CA, Sayre LM, Perry G, Carbonyl-related posttranslational modification of neurofilament protein in the neurofibrillary pathology of Alzheimer's disease, J Neurochem 64 (1995) 2660-2666.

106. Smith MA, Sayre LM, Vitek MP, Monnier VM, Perry G, Early AGEing and Alzheimer's, Nature 374 (1995) 316.

107. Smith MA, Perry G, Richey PL, Sayre LM, Anderson VE, Beal MF, Kowall N, Oxidative damage in Alzheimer's, Nature 382 (1996) 120121.

108. Smith MA, Siedlak SL, Richey PL, Nagaraj RH, Elhammer A, Perry G, Quantitative solubilization and analysis of insoluble paired helical filaments from Alzheimer disease, Brain Res 717 (1996) 99-108.

109. Smith MA, Harris PLR, Sayre LM, Beckman JS, Perry G, Widespread peroxynitrite-mediated damage in Alzheimer's disease, J Neurosci 17 (1997) 2653-2657.

110. Smith MA, Harris PLR, Sayre LM, Perry G, Iron accumulation in Alzheimer disease is a source of redox-generated free radicals, Proc Natl Acad Sci USA 94 (1997) 9866-9868.

111.Smith MA, Hirai K, Hsiao K, Pappola MA, Harris PLR, Siedlak SL, Tabaton M, Perry G, Amyloid$\beta$ deposition in Alzheimer transgenic mice initiates oxidative stress, J Neurochem (1998), in press.

112.Sorbi S, Bird ED, Blass JP, Decreased pyruvate dehydrogenase complex activity in Huntington and Alzheimer brain, Ann Neurol 13 (1983) 7278.

113. Sternberger NH, Sternberger LA, Ulrich J, Aberrant neurofilament phosphorylation in 
Alzheimer disease, Proc Natl Acad Sci USA 82 (1985) 4274-4276.

114.Stewart WF, Kawas C, Corrada M, Metter EJ, Risk of Alzheimer's disease and duration of NSAID use, Neurology 48 (1997) 626-631.

115. Stoll S, Scheuer K, Pohl O, Muller WE, Ginkgo biloba extract (EGb 761) independently improves changes in passive avoidance learning and brain membrane fluidity in the aging mouse, Pharmacopsychiatry 29 (1996) 144-149.

116.Strittmatter WJ, Weisgraber KH, Huang DY, Dong LM, Salvesen GS, Pericak-Vance M, Schmechel D, Saunders AM, Goldgaber D, Roses $\mathrm{AD}$, Binding of human apolipoprotein $\mathrm{E}$ to synthetic amyloid $\beta$ peptide: isoform-specific effects and implications for late-onset Alzheimer disease, Proc Natl Acad Sci USA 90 (1993) 8098-8102.

117.Su JH, Anderson AJ, Cummings BJ, Cotman CW, Immunohistochemical evidence for apoptosis in Alzheimer's disease, Neuroreport 5 (1994) 25292533.

118.Thal LJ, Carta A, Clarke WR, Ferris SH, Friedland RP, Petersen RC, Pettegrew JW, Pfeiffer E, Raskind MA, Sano M, Tuszynski MH, Woolson RF, A 1-year multicenter placebocontrolled study of acetyl-L-carnitine in patients with Alzheimer's disease, Neurology 47 (1996) 705-711.

119. Trojanowski JQ, Schmidt ML, Shin R-W, Bramblett GT, Goedert M, Lee VM-Y, PHF- $\tau$ (A68): From pathological marker to potential mediator of neuronal dysfunction and degeneration in Alzheimer's disease, Clin Neurosci 1 (1993) 184-191.

120. Trojanowski JQ, Mawal-Dewan M, Schmidt ML, Martin J, Lee VM, Localization of the mitogen activated protein kinase ERK2 in Alzheimer's disease neurofibrillary tangles and senile plaque neurites, Brain Res 618 (1993) 333-337.

121. Vane JR, Botting RM, Mechanism of action of aspirin-like drugs, Sem Arthritis Rheumatism 26(6 Suppl 1) (1997) 2-10.

122. Vincent I, Rosado M, Davies P, Mitotic mechanisms in Alzheimer's disease?, J Cell Biol
132 (1996) 413-425.

123. Vitek MP, Bhattacharya K, Glendening JM, Stopa E, Vlassara H, Bucala R, Manogue K, Cerami A, Advanced glycation end products contribute to amyloidosis in Alzheimer disease, Proc Natl Acad Sci USA 91 (1994) 4766-4770.

124. Wolozin B, Iwasaki K, Vito P, Ganjei JK, Lacana E, Sunderland T, Zhao B, Kusiak JW, Wasco W, D'Adamio L, Participation of presenilin 2 in apoptosis: enhanced basal activity conferred by an Alzheimer mutation, Science 274 (1996) 17101713.

125.Wu RM, Murphy DL, Chiueh CC, Suppression of hydroxyl radical formation and protection of nigral neurons by l-deprenyl (selegiline), Ann NY Acad Sci 786 (1996) 379-390.

126. Yan S-D, Chen X, Schmidt A-M, Brett J, Godman G, Zou Y-S, Scott CW, Caputo C, Frappier T, Smith MA, Perry G, Yen S-H, Stern $\mathrm{D}$, Glycated tau protein in Alzheimer disease: a mechanism for induction of oxidant stress, Proc Natl Acad Sci USA 91 (1994) 7787-7791.

127. Yan SD, Yan SF, Chen X, Fu J, Chen M, Kuppusamy P, Smith MA, Perry G, Godman GC, Nawroth P, Zweier JL, Stern D, Nonenzymatically glycated tau in Alzheimer's disease induces neuronal oxidant stress resulting in cytokine gene expression and release of amyloid $\beta$-peptide, Nature Medicine 1 (1995) 693-699.

128. Yan SD, Chen X, Fu J, Chen M, Zhu H, Roher A, Slattery T, Zhao L, Nagashima M, Morser J, Migheli A, Nawroth P, Stern D, Schmidt AM, RAGE and amyloid- $\beta$ peptide neurotoxicity in Alzheimer's disease, Nature 382 (1996) 685-691.

129. Yankner BA, Duffy LK, Kirschner DA, Neurotrophic and neurotoxic effects of amyloid beta protein: reversal by tachykinin neuropeptides, Science 250 (1990) 279-282.

130.Zhang Z, Rydel RE, Drzewiecki GJ, Fuson K, Wright S, Wogulis M, Audia JE, May PC, Hyslop PA, Amyloid beta-mediated oxidative and metabolic stress in rat cortical neurons: no direct evidence for a role for $\mathrm{H}_{2} \mathrm{O}_{2}$ generation, $\mathrm{J}$ Neurochem 67 (1996) 1595-1606. 